\title{
FACTORS INFLUENCING THE FREQUENCY OF NEST PARASITISM BY BROWN-HEADED COWBIRDS IN THE NORTHERN SIERRA NEVADA
}

\author{
Kathi L. Borgmann ${ }^{1}$ and Michael L. Morrison ${ }^{2}$
}

\begin{abstract}
Nest parasitism by Brown-headed Cowbirds (Molothrus ater) can negatively affect host populations. Landscape-scale factors, such as proximity to residential areas, equestrian riding stables, and grazing allotments, can affect the risk of nest parasitism as well as the abundance of Brown-headed Cowbirds. Recent increases in residential and recreational development along with a reduction in grazing allotments in the northern Sierra Nevada provide an opportunity to reevaluate factors that influence frequency of nest parasitism by Brown-headed Cowbirds. Frequency of nest parasitism increased as the distance to the nearest residential center and distance to the nearest equestrian riding stable decreased. Similarly, Brown-headed Cowbird abundance was negatively correlated with distance to the nearest residential center and distance to the nearest equestrian stable. To reduce the risk of nest parasitism, efforts should be devoted to (1) reducing further residential development at the wildland-urban interface and (2) educating landowners about bird feeders, which frequently attract Brown-headed Cowbirds.
\end{abstract}

Key words: nest parasitism, Brown-headed Cowbird, Molothrus ater, Sierra Nevada, Lake Tahoe.

Nest parasitism by Brown-headed Cowbirds (Molothrus ater) often reduces reproductive success of the host species (Brittingham and Temple 1983, Zanette et al. 2007). Nest parasitism has also been implicated in population declines of several species, including Southwestern Willow Flycatcher (Empidonax traillii extimus), Warbling Vireo (Vireo gilvus), and Least Bell's Vireo (Vireo bellii pusillus) (Brittingham and Temple 1983, Kus 1999, Whitfield et al. 1999, Purcell 2006). Due to the potential reduction in reproductive success as a result of nest parasitism, attention has been directed at determining the factors affecting spatial and temporal variation in the risk of nest parasitism. These factors may include spatial and temporal variation in host density, host species richness, or Brown-headed Cowbird abundance (Robinson et al. 1995, Barber and Martin 1997, Purcell and Verner 1999, Tewksbury et al. 1999). Other landscape-scale factors, such as proximity to forest edges, urban centers, residential areas, equestrian riding stables, grazing allotments, and campgrounds, can also affect the risk of nest parasitism as well as the abundance of Brownheaded Cowbirds (Verner and Ritter 1983, Rothstein et al. 1984, Young 1994, Robinson et al. 1995, Goguen and Mathews 1999, Morrison and Hahn 2002, Tewksbury et al. 2006, Howell et al. 2007, Rodewald 2009). In the eastern United States, for example, Brown-headed Cowbird abundance often increases with the amount of edge habitat and degree of forest fragmentation (Thompson and Dijak 2000, Thompson et al. 2000, Howell et al. 2007).

Although landscape features, such as degree of fragmentation and amount of forest cover or edge habitat can affect Brown-headed Cowbird abundance, factors related to foraging resources may be more tightly linked to Brown-headed Cowbird abundance (Rothstein et al. 1984, Thompson 1994, Goguen and Mathews 1999, Morrison and Hahn 2002, Tewksbury et al. 2006). Brown-headed Cowbirds are frequently associated with cattle, horses, and grazing allotments, because these areas provide rich foraging opportunities (Rothstein et al. 1984). Residential areas also provide foraging opportunities (Verner and Ritter 1983, Airola 1986), and proximity to residential areas may consequently influence Brown-headed Cowbird abundance.

Within the Lake Tahoe Basin Management Unit (administered by the USDA Forest Service), urbanization and secondary residences have increased throughout the landscape while grazing allotments have been eliminated (Murphy and Knopp 2000, Manley et al. 2009). Although grazing allotments have been

${ }^{1}$ School of Natural Resources, University of Arizona, Tucson, AZ 85721. E-mail: borgmann@email.arizona.edu

${ }^{2}$ Department of Wildlife and Fisheries Sciences, Texas A\&M University, College Station, TX 77843. 
eliminated, 3 equestrian riding stables (hereafter, riding stables) remain in operation along the south and east shores of Lake Tahoe, providing rich foraging opportunities for Brownheaded Cowbirds. Residential areas also provide rich foraging opportunities (e.g., bird feeders) that often attract Brown-headed Cowbirds (Airola 1986).

We addressed landscape-scale features previously shown to influence both the frequency of nest parasitism and the abundance of Brownheaded Cowbirds. These features include elevation (Purcell and Verner 1999), distance to residential centers (Verner and Ritter 1983, Airola 1986, Chace et al. 2003), and distance to riding stables (Verner and Ritter 1983, Rothstein et al. 1984). Specifically, we asked (1) if elevation, distance to residential centers, or distance to riding stables influenced the abundance of Brown-headed Cowbirds and (2) if cowbird abundance, distance to residential centers, or distance to riding stables influenced the frequency of nest parasitism at 16 sites throughout the Lake Tahoe Basin in the Sierra Nevada.

Studies conducted prior to the mid-1980s in the Sierra Nevada reported relatively low frequencies of nest parasitism and Brownheaded Cowbird abundance (Rothstein and Verner 1980, Verner and Ritter 1983). Although Brown-headed Cowbirds first appeared in the Yosemite Valley in 1934, detections were rare (Rothstein and Verner 1980). Recent studies have shown an increase in Brownheaded Cowbird populations and frequency of nest parasitism (Purcell 2006). Thus, in response to increasing numbers of Brown-headed Cowbirds and increasing changes in the landscape due to residential and recreational activities, we reevaluated factors that can influence abundance of Brown-headed Cowbirds and frequency of nest parasitism in the Sierra Nevada.

\section{Study Area}

We conducted surveys in riparian areas and montane meadows located within the USDA Forest Service Lake Tahoe Basin Management Unit, in South Lake Tahoe, California. The Lake Tahoe Basin is characterized by mountainous terrain surrounding a glaciated valley in the northern Sierra Nevada. Land uses within the Lake Tahoe Basin consist of a mix of permanent residences, secondary residences, commercial developments, and small-scale industries, as well as uses related to recreation and tourism (trails, riding stables, and visitor centers). For a full description of land uses see Manley et al. 2009. Land ownership is mixed: $78 \%$ federal, $8 \%$ state, $1 \%$ local, and $13 \%$ private (Nechodom et al. 2000). Although much of the Lake Tahoe Basin is under public ownership, forested patches and native vegetation are embedded within developed areas (Manley et al. 2009).

We monitored abundance of Brown-headed Cowbirds and frequency of nest parasitism at 16 meadow and riparian sites within the Lake Tahoe Basin ranging in elevation from 1600 to $2390 \mathrm{~m}$. We selected our study areas as part of a larger wildlife restoration and monitoring project (Borgmann and Morrison unpublished data). We monitored 5 meadow sites that ranged in size from 10 to 20 ha. Willows (primarily Lemmon's willow [Salix lemmonii] and Geyer willow [Salix geyeriana]), grasses, sedges (Carex spp.), rushes (Juncus spp.), and herbaceous flowering plants occurred within each meadow study site. Mixed conifer forest consisting of lodgepole pine (Pinus contorta), white fir (Abies concolor), and Jeffrey pine (Pinus jeffreyi) surrounded each montane meadow. Small patches of quaking aspen (Populus tremuloides) also occurred along the edges of meadows. We also monitored 12 riparian study sites containing willows and mountain alder (Alnus incana tenuifolia) adjacent to a stream with mixed conifer forest (lodgepole pine and white fir) in the uplands bordering the riparian area.

\section{Methods}

We established avian point-count stations to estimate Brown-headed Cowbird abundance around the perimeter of each meadow site and along the stream channel at riparian sites. We established point-count stations 200-250 m apart at each site. The number of point-count stations at each site varied by the size of the meadow and riparian area. We surveyed each site 3 times separated by one week during June 2004-2008; however, we did not survey all sites in every year of the study (Table 1). Variation in annual surveys at each site was due to changes in funding priorities and the addition of study sites for restoration projects. Point counts began 15 minutes before sunrise 
TABLE 1. Average number (SE) of Brown-headed Cowbirds detected at point-count stations from 2004 to 2008 at meadow and riparian study sites in the Lake Tahoe Basin, California.

\begin{tabular}{lccccc}
\hline Site & 2004 & 2005 & 2006 & 2007 & 2008 \\
\hline Burton Creek & $10.0(2.3)$ & $-{ }^{\mathrm{a}}$ & $6.3(1.5)$ & - & - \\
Big Meadow & $6.3(2.0)$ & $1.7(0.9)$ & $2.3(0.3)$ & $3.0(1.0)$ & $0.3(0.3)$ \\
Blackwood Creek & $5.6(0.3)$ & - & $6.7(1.2)$ & $2.3(1.2)$ & - \\
Cookhouse Meadow & $2.3(0.9)$ & $0.0(0.0)$ & $2.7(0.3)$ & $2.7(0.7)$ & $1.3(0.7)$ \\
Fountain Place Meadow & - & - & $1.3(0.9)$ & $4.0(0.6)$ & $0.7(0.3)$ \\
General Creek & $7.0(2.0)$ & - & $7.7(1.9)$ & $7.3(1.3)$ & - \\
Grass Lake Meadow & $2.3(0.7)$ & $1.3(0.9)$ & $1.0(0.0)$ & $0.7(0.3)$ & - \\
High Meadow & - & - & $3.7(0.3)$ & $3.7(0.9)$ & $0.7(0.7)$ \\
Meeks Creek & $13.3(2.9)$ & - & $11.0(1.5)$ & $8.3(2.3)$ & - \\
McKinney Creek & $7.0(1.0)$ & - & $2.0(1.0)$ & $1.7(1.2)$ & - \\
Sunset Reach Creek & - & - & $7.3(1.3)$ & - & $5.3(1.5)$ \\
Upper Truckee Meadow & $6.0(0.0)$ & - & - & - & $5.0(1.2)$ \\
Tallac Meadow & $10.3(2.3)$ & - & $4.7(1.3)$ & - & $11.7(1.2)$ \\
Trout Creek & - & - & - & - & $2.7(0.9)$ \\
Taylor Meadow & $12.3(1.8)$ & - & $7.7(2.4)$ & - & - \\
Ward Creek & $7.3(1.5)$ & - & $1.0(1.0)$ & - & - \\
\hline
\end{tabular}

aDashes indicate that the site was not surveyed.

and finished no later than 4 hours after sunrise. Observers recorded all birds seen or heard within $50 \mathrm{~m}$ of the point-count station for 10 minutes at each point. Observers did not conduct point counts during inclement weather (e.g., precipitation or wind $>9 \mathrm{~km} \cdot \mathrm{h}^{-1}$ ). We calculated average Brown-headed Cowbird abundance by dividing the total number of Brown-headed Cowbirds detected across all point-count stations by the number of visits for each year.

We searched for and monitored nests of 7 focal species: Willow Flycatcher, Dusky Flycatcher (Empidonax oberholseri), Warbling Vireo, Yellow Warbler (Dendroica petechia), MacGillivray's Warbler (Oporornis tolmiei), Wilson's Warbler (Wilsonia pusilla), and Song Sparrow (Melospiza melodia) to quantify the frequency of nest parasitism by Brown-headed Cowbirds. We chose to monitor these species for several reasons: (1) they typically nest $<5$ $m$ from the ground, which allows for easier observation of nest contents; (2) some are species of concern (e.g., Willow Flycatcher, Yellow Warbler) within the Lake Tahoe Basin; (3) they are associated with riparian and meadow communities; and (4) they are known Brown-headed Cowbird hosts (Purcell and Verner 1999). We monitored nests every 3-5 days until nest outcome could be determined. We considered a nest parasitized if we detected the presence of a Brown-headed Cowbird egg or nestling. We calculated frequency of nest parasitism by dividing the number of nests found containing a Brown-headed Cowbird egg or nestling by the total number of nests found per species at each site in each year.

We used land-cover data provided by the Tahoe Regional Planning Agency to determine the location of residential areas and riding stables surrounding Lake Tahoe (Tahoe Regional Planning Agency 2004). Land-cover data was divided into polygons based on land uses. Residential polygons were classified as areas within current residential neighborhoods, areas within the urban boundary that are serviced by utilities, and areas serviced by commercial and public facilities (Tahoe Regional Planning Agency 2004). To determine the distance from our study sites to the nearest residential area and riding stable, we used ArcMap version 9.1 to measure the distance from each study site to the center of the closest residential or riding stable polygon.

\section{Statistical Analyses}

We used general linear models to determine if current features of the landscape, in particular residential areas and riding stables, influenced (1) Brown-headed Cowbird abundance (model 1: Brown-headed Cowbird abundance $=$ distance to residential centers + distance to riding stables + year) and (2) frequency of nest parasitism (model 2: frequency of nest parasitism $=$ distance to residential centers + distance to riding stables + Brown-headed Cowbird abundance + species + year). Although Brownheaded Cowbird abundance has been shown to vary with elevation (Purcell and Verner 1999), we did not include elevation in our models 


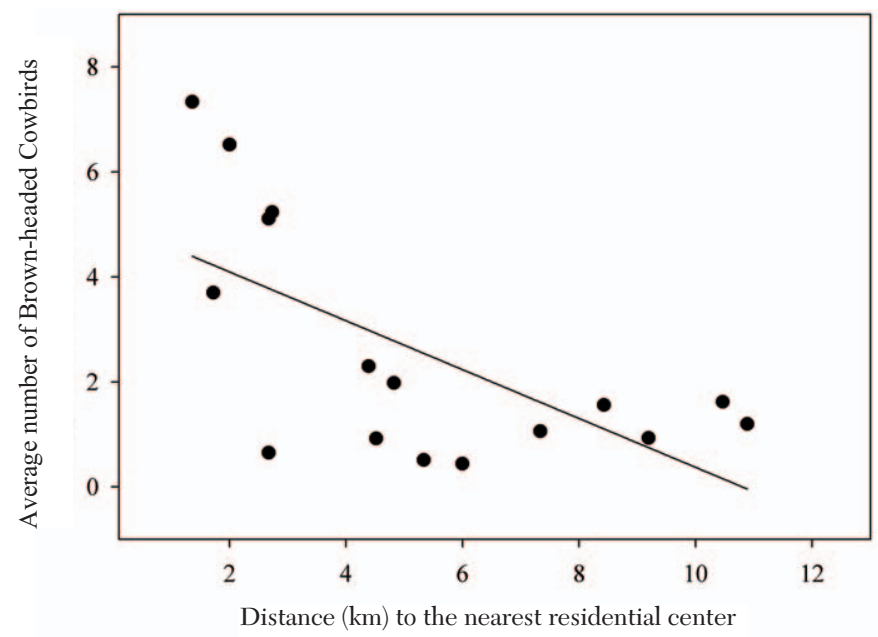

Fig. 1. Brown-headed Cowbird abundance was negatively correlated with distance to the nearest residential center in the Lake Tahoe Basin, California.

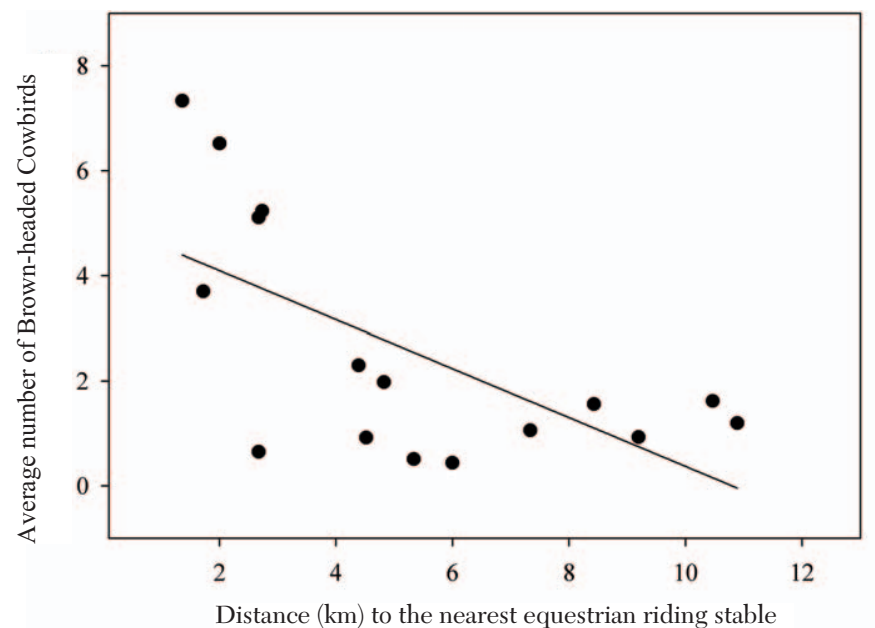

Fig. 2. Brown-headed Cowbird abundance was negatively correlated with distance to the nearest riding stable in the Lake Tahoe Basin, California.

because elevation was correlated with distance to residential centers $(r=0.955)$. Distance to the nearest residential center and distance to the nearest riding stable were uncorrelated $(r$ $=0.406)$. We included year as a covariate in model 1 and year and species as covariates in model 2. To improve normality, we squareroot transformed Brown-headed Cowbird abundance and arcsine square-root transformed the percent of nests parasitized. All statistical analyses were performed using SAS version 9.2 (SAS Institute 2008) with $\alpha=0.05$.

\section{RESULTS}

Brown-headed Cowbird abundance varied across years and sites (Table 1). Average Brownheaded Cowbird abundance was greatest at Meeks Creek and Taylor Meadow (Table 1). All study sites were located within $12 \mathrm{~km}$ of the nearest residential center $(3.20, \mathrm{SE}=2.27$, range $0.44-7.33$ ), and 9 sites were located within $12 \mathrm{~km}$ of the nearest riding stable (14.27, $\mathrm{SE}=6.57$, range 1.38-26.65). Brownheaded Cowbird abundance was influenced 


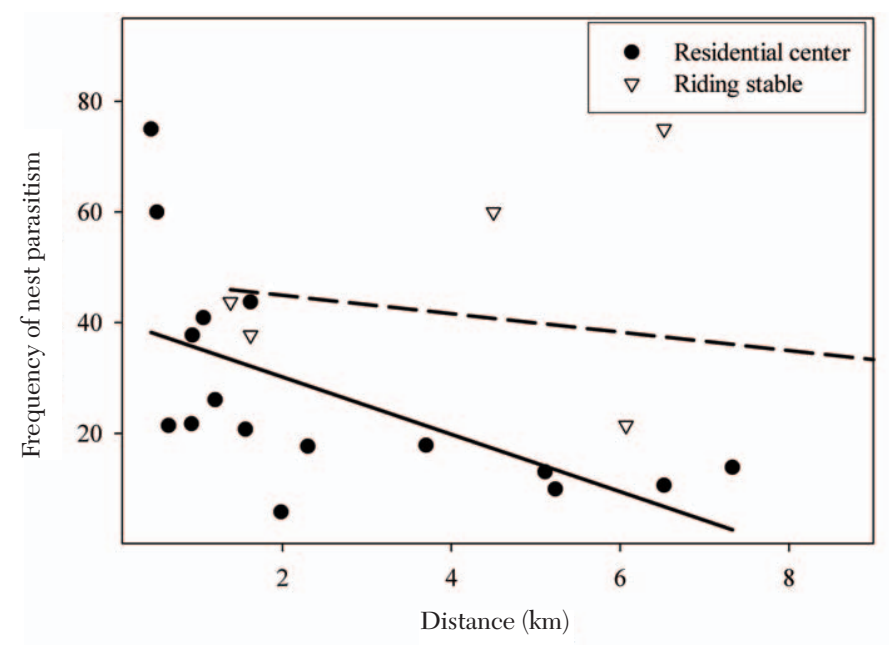

Fig. 3. Frequency of nest parasitism of 7 species was negatively correlated with distance to the nearest residential center (solid line) and riding stable (dashed line) in the Lake Tahoe Basin, California.

TABLE 2. Number of nests monitored from 2004 to 2008 and the frequency of nest parasitism for 7 species at meadow and riparian study sites in the Lake Tahoe Basin, California.

\begin{tabular}{lcc}
\hline Species & $\begin{array}{c}\text { Number of } \\
\text { nests monitored }\end{array}$ & $\begin{array}{c}\text { Frequency of } \\
\text { parasitism (\%) }\end{array}$ \\
\hline Warbling Vireo & 224 & 12.9 \\
Willow Flycatcher & 4 & 0.0 \\
Dusky Flycatcher & 258 & 5.0 \\
MacGillivray's Warbler & 58 & 36.2 \\
Wilson's Warbler & 221 & 33.0 \\
Yellow Warbler & 49 & 30.6 \\
Song Sparrow & 24 & 29.2 \\
\hline
\end{tabular}

by distance to residential centers and riding stables, after controlling for differences in abundance across years $\left(F_{6,45}=11.28, P<\right.$ 0.001). Abundance of Brown-headed Cowbirds increased with decreasing distance to residential centers $\left(F_{1}=17.82, P<0.001\right.$; Fig. $1)$ and distance to the nearest riding stable $\left(F_{1}\right.$ $=5.12, P=0.029$; Fig. 2).

We monitored 838 nests of 7 species from 2004 to 2008 , of which $19 \%$ (158) were parasitized by Brown-headed Cowbirds. Frequency of parasitism varied by host species (Table 2), from $5 \%$ in Dusky Flycatchers $(n=258)$ to $36 \%$ in MacGillivray's warblers $(n=58)$. The frequency of Brown-headed Cowbird nest parasitism was influenced by distance to the nearest riding stable and distance to the nearest residential center, after controlling for differences among years and species (Table 3). In
TABLE 3. General linear model results of the effects of Brown-headed Cowbird abundance, distance to residential centers, and distance to riding stables on the frequency of nest parasitism. Frequency of nest parasitism by Brownheaded Cowbirds was influenced by distance to residential centers and riding stables in the Lake Tahoe Basin, California.

\begin{tabular}{lcrr}
\hline Variable & df & \multicolumn{1}{c}{$F$} & \multicolumn{1}{c}{$P$} \\
\hline Average number of cowbirds & 1 & 2.65 & 0.106 \\
Year & 4 & 0.94 & 0.442 \\
Species & 6 & 4.83 & $<0.001$ \\
Distance to residential center & 1 & 5.81 & 0.017 \\
Distance to riding stable & 1 & 11.22 & 0.001 \\
\hline
\end{tabular}

particular, the frequency of Brown-headed Cowbird nest parasitism increased with decreasing distance to the nearest riding stable and residential centers (Table 3, Fig. 3). Nest parasitism frequency also increased marginally with increasing Brown-headed Cowbird abundance (Table 3).

\section{Discussion}

In the Lake Tahoe Basin, Brown-headed Cowbird abundance increased with decreasing distance to residential centers and riding stables. We also found that frequency of nest parasitism increased with proximity to residential centers and riding stables. Similarly, Brown-headed Cowbird abundance and risk of nest parasitism has increased in other urbanizing landscapes (Chace et al. 2003, 
Burhans and Thompson 2006, Tewksbury et al. 2006, Rodewald 2009). Increased abundance of Brown-headed Cowbirds is likely the result of increased foraging opportunities (e.g., bird feeders and livestock) in residential areas and near riding stables (Verner and Ritter 1983, Rothstein et al. 1984, Airola 1986, Goguen and Mathews 1999, Morrison and Hahn 2002, Chace et al. 2003). More than $80 \%$ of respondents to a survey reported that they feed wildlife around their home, and $96 \%$ of those reported feeding birds (USFWS and Census Bureau 2006). Bird feeding may contribute to increased foraging opportunities for Brownheaded Cowbirds; however, we lack the data to quantify the direct effects of bird feeders on Brown-headed Cowbird abundance. Teasing apart the effects of residential areas versus riding stables on Brown-headed Cowbird abundance is also complicated by the fact that riding stables are located near residential areas. However, both residential centers and riding stables are likely contributing to increased abundance of Brown-headed Cowbirds in the Lake Tahoe Basin.

Because an increase in foraging sites (e.g., bird feeders, urban lawns, and riding stables) at the wildland-urban interface can increase the risk of parasitism for birds nesting near the wildland-urban interface (Chace et al. 2003), we suggest educating landowners about the potential problems of attracting Brown-headed Cowbirds by feeding birds within the wildland-urban interface. Eliminating bird feeders, especially in remote or isolated areas surrounded by forested habitat, will likely reduce the frequency of nest parasitism (Tewksbury et al. 2006). Although maintaining clean riding stables may reduce the attractiveness of the area to Brown-headed Cowbirds, continually removing all animal and food waste in a commercial stable is unfeasible. Localized trapping of Brown-headed Cowbirds at the riding stable could be implemented as a remedial action to minimize the attraction of Brown-headed Cowbirds to the livestock while allowing this recreational activity to continue. The trapping and removal of Brown-headed Cowbirds can be an effective short-term means of reducing nest parasitism in local geographic areas (Whitfield et al. 1999, Morrison and AverillMurray 2002, Smith et al. 2002). However, Brown-headed Cowbird trapping is not a longterm solution and does not always result in reduced levels of nest parasitism (Hall and Rothstein 1999, Sandercock et al. 2008).

\section{ACKNOWLEDGMENTS}

We thank A. Arens, W. Beard, L. Caldwell, U. Carliss, M. Comer, R. Evans, S. Eyes, L. Foerster, K. Gagnon, D. Gaube, M. Grammond, T. Hanks, N. Hatton, M. Holdgate, G. Johnson, H. Kaplan, J. Kendrick, C. Kim, G. Levandoski, E. Liebgold, M. Linnell, D. Maxwell, J. McClure, B. McNall, B. Ogle, L. Orr, T. Raabe, J. Rainbolt, T. Ransom, T. Rodriquez, D. Rios, B. Schielke, J. Scott, J. Shrum, J. Slaughter, H. Sofaer, B. Spirou, W. Standish, D. Stetson, $\mathrm{H}$. Tretten, and T. Valentine for field assistance. We also thank L. Fields and California State Parks for allowing access to field sites. Special thanks to J. Roth, V. Lyon, and numerous USDA Forest Service employees for assisting with logistics and creating a friendly research environment. The USDA Forest Service, Lake Tahoe Basin Management Unit provided funding through the Southern Nevada Public Land Management Act. E. Litchfield and M. Belk provided valuable comments that greatly improved the manuscript.

\section{Literature Cited}

Airola, D.A. 1986. Brown-headed Cowbird parasitism and habitat disturbance in the Sierra Nevada. Journal of Wildlife Management 50:571-575.

Barber, D.R., AND T.E. MARTIN. 1997. Influence of alternate host densities on Brown-headed Cowbird parasitism rates in Black-capped Vireos. Condor 99: 595-604.

Brittingham, M.C., AND S.A. Temple. 1983. Have cowbirds caused forest songbirds to decline? BioScience 33: $31-35$.

Burhans, D.E., AND F.R. Thompson. 2006. Songbird abundance and parasitism differ between urban and rural shrublands. Ecological Applications 16:394-405.

Chace, J.F., J.J. Walsh, A. Cruz, J.W. Prather, and H.M. SWANSON. 2003. Spatial and temporal activity patterns of the brood parasitic Brown-headed Cowbird at an urban/wildland interface. Landscape and Urban Planning 64:179-190.

Goguen, C.B., And N.E. Mathews. 1999. Review of the causes and implications of the association between cowbirds and livestock. Studies in Avian Biology 18: 10-17.

Hall, L.S., AND S.I. Rothstein. 1999. Cowbird control: the efficacy of long-term control and proposed alternatives to standard control practices. Studies in Avian Biology 18:254-259.

Howell, C.A., W.D. Dijak, and F.R. Thompson. 2007. Landscape context and selection for forest edge by breeding Brown-headed Cowbirds. Landscape Ecology 22:273-284. 
Kus, B.E. 1999. Impacts of Brown-headed Cowbird parasitism on productivity of the endangered Least Bell's Vireo. Studies in Avian Biology 18:160-166.

Manley, P.N., S.A. Parks, L.A. Campbell, and M.D. SCHLESINGER. 2009. Modeling urban land development as a continuum to address fine-grained habitat heterogeneity. Landscape and Urban Planning 89: 28-36.

Morrison, M.L., AND A. Averill-Murray. 2002. Evaluating the efficacy of manipulating cowbird parasitism on host nesting success. Southwestern Naturalist 47: 236-243.

Morrison, M.L., AND D.C. HAHN. 2002. Geographical variation in cowbird distribution, abundance, and parasitism. Studies in Avian Biology 25:65-72.

MurPhy, D.M., AND C.M. KNOPP. 2000. Lake Tahoe watershed assessment: U.S. Forest Service General Technical Report PSW-GTR-175

Nechodom, M., R. Rowntree, N. Dennis, H. Robinson, AND J. Goldstein. 2000. Social, economic, and institutional assessment. Pages 601-687 in D.D. Murphy and C.M. Knopp, editors, Lake Tahoe Watershed Assessment: Volume I. General Technical Report PSW-GTR-175, Pacific Southwest Research Station, Forest Service, Berkeley, CA. U.S. Department of Agriculture, Albany, CA. 753 pp.

PurCELL, K.L. 2006. Abundance and productivity of Warbling Vireos across an elevational gradient in the Sierra Nevada. Condor 108:315-325.

Purcell, K.L., AND J. Verner. 1999. Abundance and rates of brood parasitism by Brown-headed Cowbirds over an elevational gradient in the southern Sierra Nevada. Studies in Avian Biology 18:97-103.

Robinson, S.K., S.I. Rothstein, M.C. Brittingham, L.J. PETIT, AND J.A. GRZYBOWSKI. 1995. Ecology of cowbirds and their impact on host populations. Pages 428-460 in T.E. Martin and D.M. Finch, editors, Ecology and management of neotropical migratory birds. Oxford University Press, New York, NY.

RODEWALD, A.D. 2009. Urban-associated habitat alteration promotes brood parasitism of Acadian Flycatchers. Journal for Field Ornithology 80:234-241.

Rothstein, S.I., And J. Verner. 1980. Range expansion and diurnal changes in dispersion of the Brownheaded Cowbird in the Sierra Nevada. Auk 97: 253-267.

Rothistein, S.I., J. Verner, and E. Stevens. 1984. Radiotracking confirms a unique diurnal pattern of spatial occurrence in the parasitic Brown-headed Cowbird (Molothrus ater). Ecology 65:77-88.

Sandercock, B.K., E.L. Hewett, and K.L. Kosciuch. 2008. Effects of experimental cowbird removals on brood parasitism and nest predation in a grassland songbird. Auk 125:820-830.

SAS Institute, Inc. 2008. SAS. Version 9.2. Cary, NC.

Smith, J.N.M., M.J. TAITT, AND L. ZanetTE. 2002. Removing Brown-headed Cowbirds increases seasonal fecundity and population growth in Song Sparrows. Ecology 83:3037-3047.

Tahoe Regional Planning Agency. 2004. Regional plan for the Lake Tahoe Basin: goals and policies. Available from: http://www.trpa.org/documents/docdwnlds/goals .pdf

Tewksbury, J.J., L. Garner, S. Garner, J.D. Lloyd, V. SAAB, AND T.E. Martin. 2006. Tests of landscape influence: nest predation and brood parasitism in fragmented ecosystems. Ecology 87:759-768.

Tewksbury, J.J., T.E. Martin, S.J. Hejl, T.S. Redman, AND FJ. WHEELER. 1999. Cowbirds in a western valley: effects of landscape structure, vegetation, and host density. Studies in Avian Biology 18:22-33.

Thompson, F.R., III. 1994. Temporal and spatial patterns of breeding Brown-headed Cowbirds in the midwestern United States. Auk 111:979-990.

Thompson, F.R., III, AND W.D. DiJaK. 2000. Movements, home range, and habitat preferences of female Brownheaded Cowbirds in three midwestern landscapes. Pages 100-109 in T. Cook, S.K. Robinson, S.I. Rothstein, S.G. Sealy, and J.N.M. Smith, editors, Ecology and management of cowbirds. University of Texas Press, Austin, TX.

Thompson, F.R., III, S.K. Robinson, T.M. Donovan, J. FAABORG, AND D.R. WhitEHEAD. 2000. Biogeographic, landscape, and local factors affecting cowbird abundance and host parasitism levels. Pages 271-279 in T. Cook, S.K. Robinson, S.I. Rothstein, S.G. Sealy, and J.N.M. Smith, editors, Ecology and management of cowbirds. University of Texas Press, Austin, TX.

[USFWS and Census Bureau] U.S. Department of the INTERIOR, Fish AND WILdLIFE SERVICE, and U.S. Department of Commerce, U.S. Census Bureau. 2006. 2006 National Survey of Fishing, Hunting, and Wildlife-Associated Recreation. Available from: http:// www.census.gov/prod/2008pubs/fhw06-nat.pdf

Verner, J., AND L.V. RitTer. 1983. Current status of the Brown-headed Cowbird in the Sierra National Forest. Auk 100:355-368.

Whitfield, M.J., K.M. Enos, and S.P. Rowe. 1999. Is Brown-headed Cowbird trapping effective for managing populations of the endangered Southwestern Willow Flycatcher? Studies in Avian Biology 18: 260-266.

YounG, B.E. 1994. The effects of food, nest predation and weather on the timing of breeding in tropical House Wrens. Condor 96:341-353.

Zanette, L., D.T. Haydon, J.N.M. Smith, M.J. TaitT, AND M. Clinchy. 2007. Reassessing the cowbird threat. Auk 124:210-223.

Received 10 March 2009

Accepted 18 November 2009 